\title{
Karakteristik Geokimia Basal Alkali Formasi Manamas di Sungai Bihati, Baun, Pulau Timor
}

\author{
Geochemical Characteristics of Alkaline Basalt Manamas Formation \\ in The Bihati River, Baun, Timor Island
}

\author{
Angga Jati Widiatama ${ }^{1,2 *}$, Lauti Dwita Santy ${ }^{3}$, Happy Christin Natalia ${ }^{1}$, \\ Joko Wahyudiono ${ }^{3}$, Rinaldi Ikhram ${ }^{1}$ \\ ${ }^{1}$ Program Teknik Geologi, Institut Teknologi Sumatera \\ ${ }^{2}$ Pusat Riset dan Inovasi Teknologi Kebumian dan Mineral, Institut Teknologi Sumatera \\ J1. Terusan Ryacudu, Kabupaten Lampung Selatan, Lampung, Indonesia, 35365 \\ ${ }^{3}$ Pusat Survei Geologi, Badan Geologi, \\ Jl. Diponegoro No.57, Kota Bandung, Jawa Barat, Indonesia, 40122 \\ *E-mail: angga.widiatama@gl.itera.ac.id
}

Naskah diterima: 19 Januari 2021, direvisi: 19 Maret 2021, disetujui: 3 Mei 2021

DOI: 10.17146/eksplorium.2021.42.1.6205

\begin{abstract}
ABSTRAK
Batuan beku Formasi Manamas di Sungai Bihati, Baun merupakan salah satu singkapan batuan beku di Pulau Timor yang belum banyak diteliti berdasarkan karakter geokimia. Penelitian ini bertujuan untuk mengetahui genesa dan proses yang terjadi pada batuan beku Formasi Manamas dalam kerangka tektonik yang terjadi di Pulau Timor berdasarkan analisis petrografi dan geokimia. Analisis geokimia dilakukan dengan menggunakan $X$-ray Fluorescence (XRF) dan Inductively Coupled Plasma-mass Spectrometery (ICP-MS) untuk mengetahui senyawa utama, unsur jejak, dan unsur tanah jarang. Batuan beku Formasi Manamas berupa intrusi basal dengan afinitas alkali yang menunjukkan pola pengayaan unsur tanah jarang yang identik dengan Ocean Island Basalt (OIB). Penelitian ini membuktikan adanya dua mekanisme pengayaan unsur yang berbeda yaitu fluid related enrichment yang berkaitan dengan aktifitas subduksi lempeng Samudra Hindia di bawah Busur Banda dan melt related enrichment yang diperkirakan berasal dari sisa lempeng Samudra Hindia yang patah yang masuk kedalam zona reservoir OIB. Kedua magma lalu bercampur dan mengalami underplating di bawah Busur Banda.
\end{abstract}

Kata kunci: Pulau Timor, geokimia, basal alkali, ocean-island basalt

\begin{abstract}
The igneous rock of Manamas Formation in the Bihati River, Baun is one of the igneous rock outcrops in Timor Island that has not been widely studied based on its geochemical characteristic. This study aims to determine the genesis and processes that occur in the igneous rocks of the Manamas Formation within tectonic framework of Timor Island based on petrographic and geochemical analysis. X-ray Fluorescence (XRF) and Inductively Coupled Plasma-mass Spectrometery (ICP-MS) were used to determine the major elements, trace elements, and rare earth elements. The igneous rock of the Manamas Formation is a basalt intrusion with an alkaline affinity which shown an enrichment pattern of rare earth elements identical to Ocean Island Basalt (OIB). This study proves the existence of two different mechanisms of elemental enrichment, fluid related enrichment which related to the subduction activity of the Indian Ocean plate under the Banda Arc and also melt related enrichment which originated from the broken Indian Ocean plate which enters the OIB reservoir zone. The two different magmas then mix and underplating beneath the Banda Arc.
\end{abstract}

Keywords: Timor Island, geochemistry, alkaline basalt, ocean island basalt 


\section{PENDAHULUAN}

Penyelidikan batuan kristalin di Timor Barat telah dilakukan oleh berbagai peneliti [13] namun terhitung masih relatif sedikit dibandingkan di tempat lain di Indonesia. Penelitian geokimia batuan beku di Timor Barat menjadi penting karena mampu memberikan kontribusi yang signifikan dalam sejarah geologi dan dinamika geologi Kawasan Indonesia Timur [4], [5].

Berada di Busur Banda non-vulkanik, Pulau Timor terbentuk dari hasil kolisi antara Busur Gunung api Banda dengan tepi Benua Australia [6-8]. Tektonostratigrafi Timor dapat dibagi menjadi tiga suksesi utama yaitu Paraautokton atau suksesi Australia yang secara struktural ditindih oleh suksesi Alokton berupa batuan gunung api Banda, serta suksesi Autokton yang tersusun oleh batuan sedimen yang terendapkan saat berlangsung proses kolisi [7-9]. Penggolongan unit batuan pada daerah penelitian berdasarkan Kaneko [4], yang merupakan penyederhanaan dari penelitian sebelumnya, dibagi menjadi empat unit berbeda berdasarkan karakteristik batuannya, yaitu unit 1) Batuan sedimen kontinen tidak termetamorfisme, 2) Batuan metamorf Timor-Tanimbar, 3) Ofiolit depan busur, dan 4) Batugamping terumbu Kuarter.

Batuan ofiolit depan busur termasuk dalam Formasi Manamas [1]. Formasi Manamas telah dipelajari oleh beberapa peneliti [10-12] namun masih relatif sedikit dan belum menggambarkan karakteristik batuan beku secara lengkap. Penelitian ini diharapkan mampu memberikan informasi genesa dan proses yang terjadi dan mempengaruhi batuan, geokimia batuan, serta proses vulkanisme dalam kerangka tektonik yang terjadi di Pulau Timor.

\section{METODOLOGI}

Lokasi stasiun pengamatan berada di Sungai Bihati, Baun, Timor (Gambar 1) yang dapat ditempuh melalui perjalanan darat dengan mobil selama 3 jam dari Kupang. Uji geokimia anorganik dilakukan pada enam sampel batuan basal-andesit bertekstur afanitik hingga porfiro afanitik.

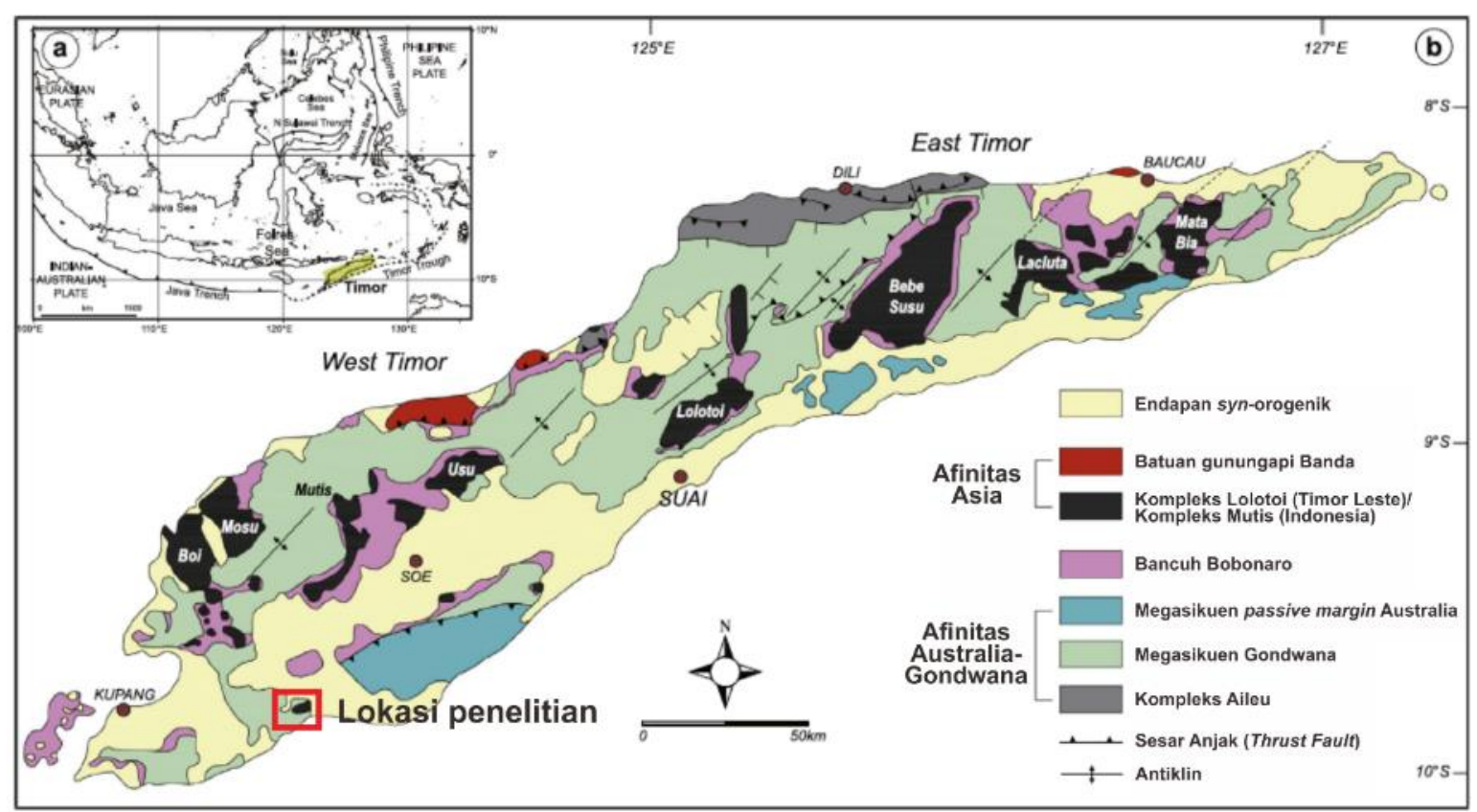

Gambar 1. Lokasi penelitian di Sungai Bihati, Baun, Pulau Timor (kotak merah). 
Sampel batuan dianalisis dengan metode $X$-ray Fluorescence (XRF) untuk pembacaan unsur utama (Tabel 1) sedangkan analisis Inductively Coupled

Plasma-Mass Spectrometery (ICP-MS) dilakukan untuk pembacaan unsur jejak dan unsur tanah jarang (Tabel 2 dan Tabel 3). Analisis dilakukan di
Laboratorium Geologi Kuarter, Badan Geologi, Kementerian ESDM dengan nilai ambang total unsur dalam preparasi sampel geokimia batuan sebesar $0,2 \%$ dari jumlah unsur yang hilang, sedangkan ambang batas loss on ignition (LOI) sebesar $4 \%$.

Tabel 1. Hasil uji XRF (dalam wt\%).

\begin{tabular}{ccccccccccccc}
\hline No & Sampel & $\mathbf{S i O}_{2}$ & $\mathbf{T i O}_{2}$ & $\mathbf{A l}_{2} \mathbf{O}_{\mathbf{3}}$ & $\mathbf{F e}_{2} \mathbf{O}_{3}$ & $\mathbf{M n O}$ & $\mathbf{C a O}$ & $\mathbf{M g O}$ & $\mathbf{N a}_{2} \mathbf{O}$ & $\mathbf{K}_{2} \mathbf{O}_{2}$ & $\mathbf{P}_{2} \mathbf{O}_{5}$ & $\mathbf{L O I}$ \\
\hline 1 & AJW123B & 33,76 & 1,61 & 10,77 & 12,12 & 0,131 & 20,62 & 1,67 & 0,856 & 4,95 & 0,6 & 14,29 \\
2 & AJW124 & 31,28 & 1,91 & 9,45 & 13,67 & 0,23 & 19,34 & 2,38 & 0,726 & 4,51 & 0,437 & 16,81 \\
3 & AJW125 & 47,28 & 1,56 & 13,2 & 12,11 & 0,137 & 5,61 & 9,06 & 2,24 & 4,44 & 1,19 & 3,92 \\
4 & AJW126 & 45,51 & 1,93 & 14,11 & 11,19 & 0,156 & 8,14 & 6,09 & 2,74 & 3,88 & 0,623 & 6,57 \\
5 & AJW127 & 22,19 & 1,95 & 9,27 & 8,49 & 0,246 & 30,77 & 1,31 & 1,45 & 2,63 & 0,458 & 20,9 \\
6 & AJW128 & 39,3 & 2,51 & 12,1 & 15,49 & 0,198 & 12,11 & 6,05 & 1,52 & 2,58 & 0,81 & 7,76 \\
\hline
\end{tabular}

Tabel 2. Hasil uji ICP-MS unsur Sc, Ti, V, Cr, Co, Ni, Cu, Zm, Ga, Rb, Sr, Y, Zr, dan Nb (dalam ppm).

\begin{tabular}{|c|c|c|c|c|c|c|c|c|c|c|c|c|c|c|c|}
\hline No & Sampel & Sc & $\mathbf{T i}$ & $\mathbf{V}$ & $\mathrm{Cr}$ & Co & $\mathbf{N i}$ & $\mathbf{C u}$ & Zn & $\mathbf{G a}$ & $\mathbf{R b}$ & $\mathrm{Sr}$ & $\mathbf{Y}$ & $\mathbf{Z r}$ & $\mathbf{N b}$ \\
\hline 1 & AJW123B & 16,0 & 11075 & 152,6 & 323,6 & 42,6 & 87,2 & 63,1 & 72,3 & 14,9 & 91,0 & 480,1 & 24,4 & 161,4 & 18,7 \\
\hline 2 & AJW124 & 13,8 & 13633 & 143,5 & 206,6 & 41,1 & 49,5 & 44,7 & 105,3 & 16,0 & 86,1 & 423,0 & 21,4 & 262,8 & 18,3 \\
\hline 3 & AJW125 & 11,0 & 9652 & 112,1 & 0,0 & 37,4 & 0,0 & 23,2 & 58,7 & 20,0 & 85,8 & 601,7 & 30,5 & 194,7 & 21,3 \\
\hline 4 & AJW126 & 13,0 & 12252 & 129,9 & 101,9 & 41,9 & 33,8 & 34,4 & 82,8 & 17,9 & 103,8 & 859,0 & 23,1 & 225,8 & 36,0 \\
\hline 5 & AJW127 & 11,8 & 14832 & 117,3 & 85,5 & 29,4 & 0,0 & 29,6 & 82,0 & 13,5 & 80,8 & 531,1 & 19,5 & 308,0 & 13,8 \\
\hline 6 & AJW128 & 15,7 & 16227 & 165,7 & 110,8 & 51,4 & 47,1 & 51,9 & 102,0 & 16,9 & 81,3 & 841,9 & 22,5 & 118,5 & 41,5 \\
\hline
\end{tabular}

Tabel 3. Hasil uji ICP-MS unsur Cs, Ba, La, Ce, Pr, Nd, Sm, Eu, Dy, Yb, Lu, Th, dan U (dalam ppm).

\begin{tabular}{ccccccccccccccc}
\hline No & Sampel & Cs & Ba & La & Ce & Pr & Nd & Sm & Eu & Dy & Yb & Lu & Th & U \\
\hline 1 & AJW123B & 2.51 & 604.81 & 33.17 & 51.70 & 7.82 & 28.22 & 5.96 & 2.17 & 4.60 & 1.71 & 0.32 & 3.80 & 0.93 \\
2 & AJW124 & 2.50 & 615.57 & 35.71 & 50.81 & 8.66 & 31.12 & 6.28 & 2.09 & 4.21 & 1.45 & 0.23 & 4.33 & 1.04 \\
3 & AJW125 & 2.76 & 746.53 & 43.43 & 83.66 & 13.91 & 48.81 & 9.50 & 3.16 & 6.15 & 1.93 & 0.29 & 8.30 & 2.14 \\
4 & AJW126 & 2.91 & 947.72 & 57.17 & 73.45 & 11.62 & 39.02 & 7.05 & 2.48 & 4.45 & 1.68 & 0.27 & 8.03 & 3.76 \\
5 & AJW127 & 2.37 & 564.71 & 39.90 & 51.79 & 9.04 & 31.70 & 6.01 & 1.98 & 3.86 & 1.38 & 0.22 & 3.99 & 0.77 \\
6 & AJW128 & 2.88 & 827.13 & 40.83 & 57.00 & 9.66 & 34.76 & 6.80 & 2.45 & 4.47 & 1.49 & 0.23 & 4.27 & 1.16 \\
\hline
\end{tabular}

Analisis perbandingan unsur jejak logam immobile dan logam mobile digunakan untuk mengidentifikasi karakteristik afinitas magma. Analisis karakteristik magma pembentuk batuan dilakukan dengan normalisasi terhadap chondrite dan primitive mantle [13]. Kombinasi unsur jejak dan unsur tanah jarang digunakan untuk mengetahui tataan tektonik dari berbagai diagram diskriminan.

\section{HASIL PENELITIAN}

Pengamatan lapangan menunjukkan batuan berstruktur masif, berwarna hitam kehijauan (Gambar 2), memiliki struktur lava bantal hingga kekar kolom, dan bertekstur afanitik hingga porfiritik dengan komponen plagioklas dan piroksen sebagai fenokris. Karakter petrologi tersebut mengindikasikan batuan beku intrusif dangkal hingga ekstrusif. 


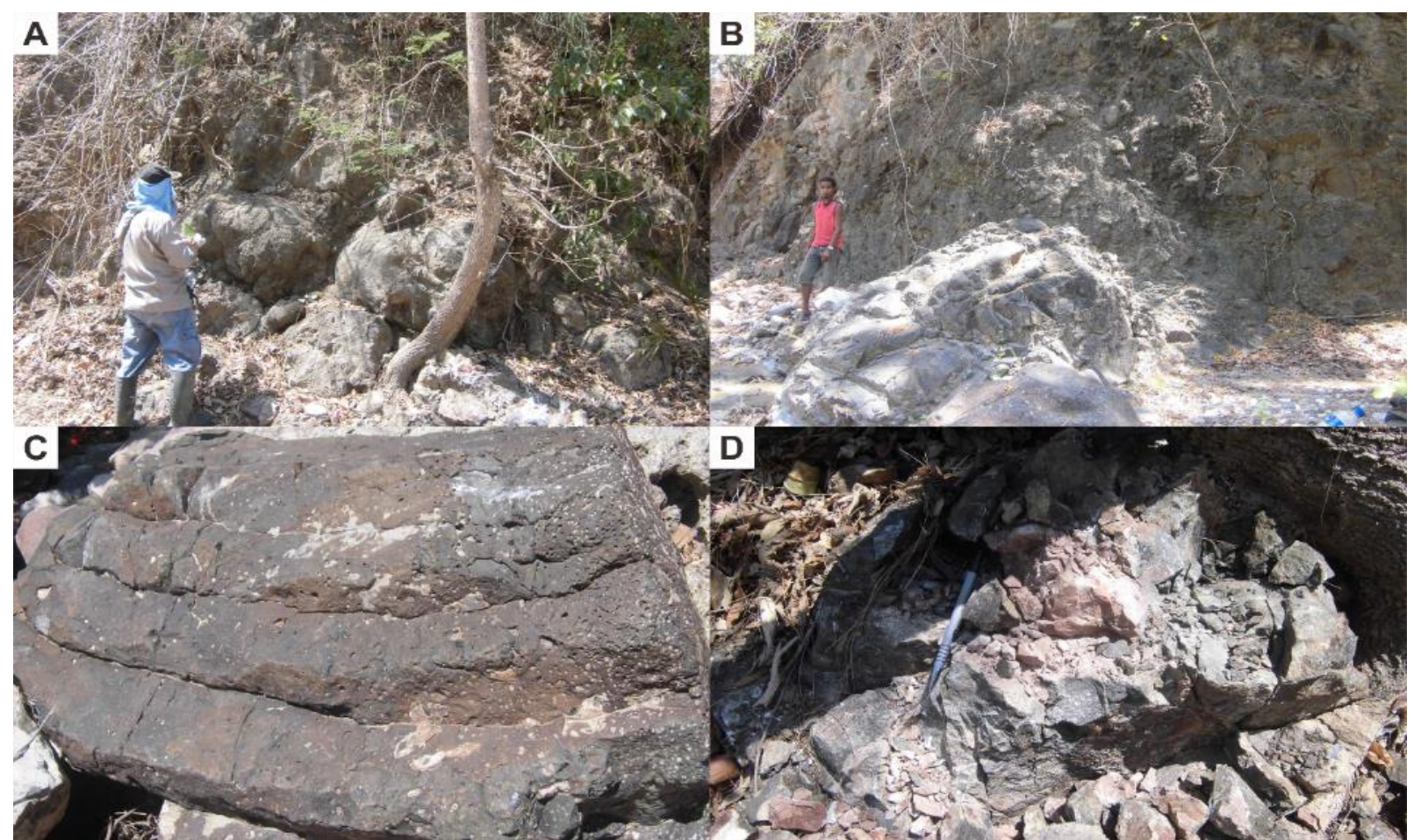

Gambar 2. Singkapan basal alkali Formasi Manamas di Sungai Bihati, Baun, Timor. (a) dan (b) Struktur bantal pada basal alkali, (c) struktur kekar kolom pada lava basal, dan (d) inklusi batuan sedimen didalam tubuh basal.

Hasil pengamatan petrografi menunjukkan batuan memiliki tekstur faneroporfiritik hingga porfiroafanitik. Mineral plagioklas, orthopiroksen, dan augit menjadi fenokris yang tertanam pada masadasar plagioklas mikrokristalin (Gambar 3a). Terdapat beberapa jenis tekstur petrografi antara lain trakitik/aliran, sieve, rim atau halo titanomagnetit yang mengelilingi orthopiroksen, dan zoning. Tekstur trakhitik/aliran mengindikasikan adanya orientasi penjajaran mineral akibat aliran magma [14]. Tekstur sieve atau rusaknya kristal plagioklas (Gambar 3b) mengindikasikan adanya percampuran magma lingkungan pembentuk kristal plagioklas [14]. Terbentuknya tekstur rim atau halo titanomagnetit yang mengelilingi orthopiroksen (Gambar 3c) mengindikasikan adanya magma baru bersuhu lebih tinggi yang masuk ke dalam lingkungan pembentukan orthopiroksen [14]. Tekstur zoning pada plagioklas mengindikasikan pertumbuhan kristal plagioklas pada lingkungan yang memiliki perubahan suhu [14]. Menurut klasifikasi berdasarkan komposisi mineral batuan beku Streckeisen [15] batuan di daerah penelitian adalah Basal.

Berdasarkan hasil uji XRF, sampel batuan memiliki LOI rata-rata lebih dari 4\% sehingga diperlukan kehati-hatian dalam mengintepretasikan unsur utama karena dikhawatirkan telah mengalami pengayaan secara sekunder sehingga tidak mencerminkan kondisi saat batuan terbentuk. Basal pada daerah penelitian menunjukkan karakteristik tingginya unsur $\mathrm{Na}_{2} \mathrm{O}(0,73-2,74 \mathrm{wt} \%), \mathrm{K}_{2} \mathrm{O}$ (2,56-4,95 wt\%), dan $\mathrm{CaO}(5,61-30,77 \mathrm{wt} \%)$ yang mengindikasikan asimilasi magma dengan kerak kontinen. Selain itu nilai unsur titanium lebih besar dari 1,25 wt\%, yaitu 1,56$2,51 \mathrm{wt} \%$, sehingga dapat diintepretasikan bahwa magma pembentuk batuan bukan berasal dari peleburan kerak samudra akibat subduksi. 


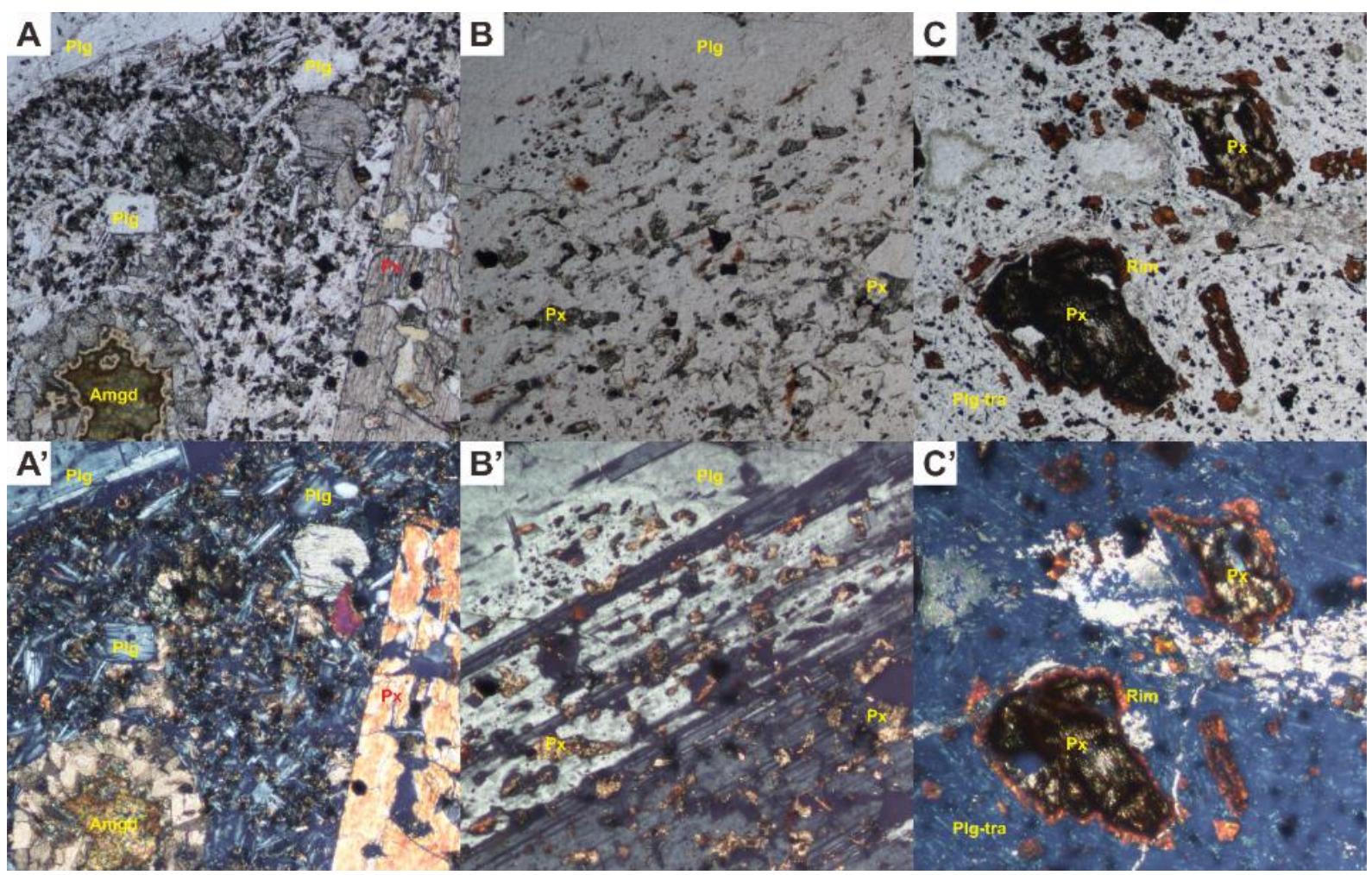

Gambar 3. Petrografi basal alkali Formasi Manamas, pengamatan dengan nikol sejajar (atas), nikol bersilang (bawah). (a) Basal dengan mikrokristal plagioklas, (b) Plagioklas dengan tekstur sieve, dan (c) Piroksen dengan tekstur rim pada bagian tepinya dengan masa dasar mikrokristal plagioklas bertekstur aliran/trakitik.

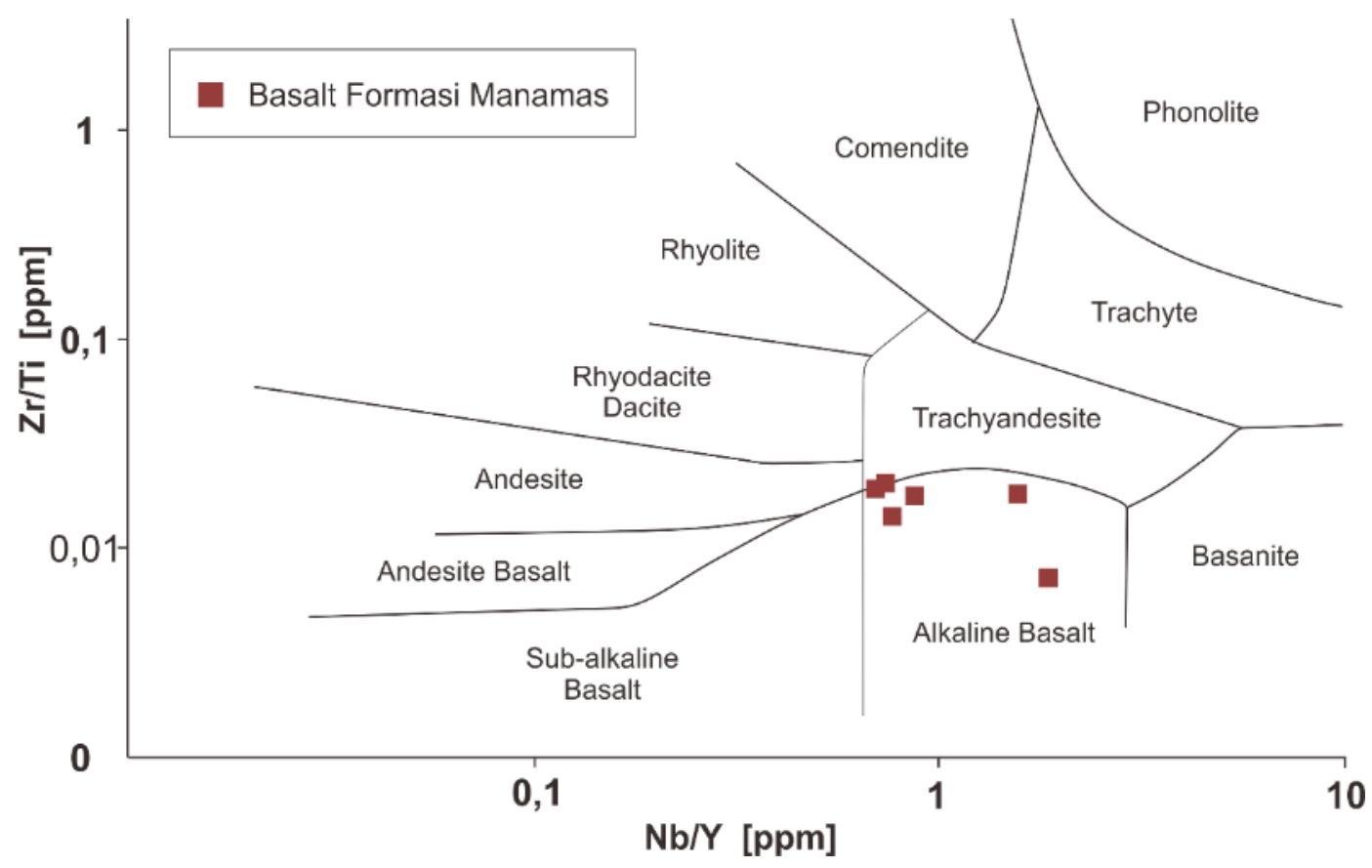

Gambar 4. Diagram diskriminan batuan beku Zr/Ti vs Nb/Y [16] menunjukkan batuan pada daerah penelitian berupa basal alkali. 

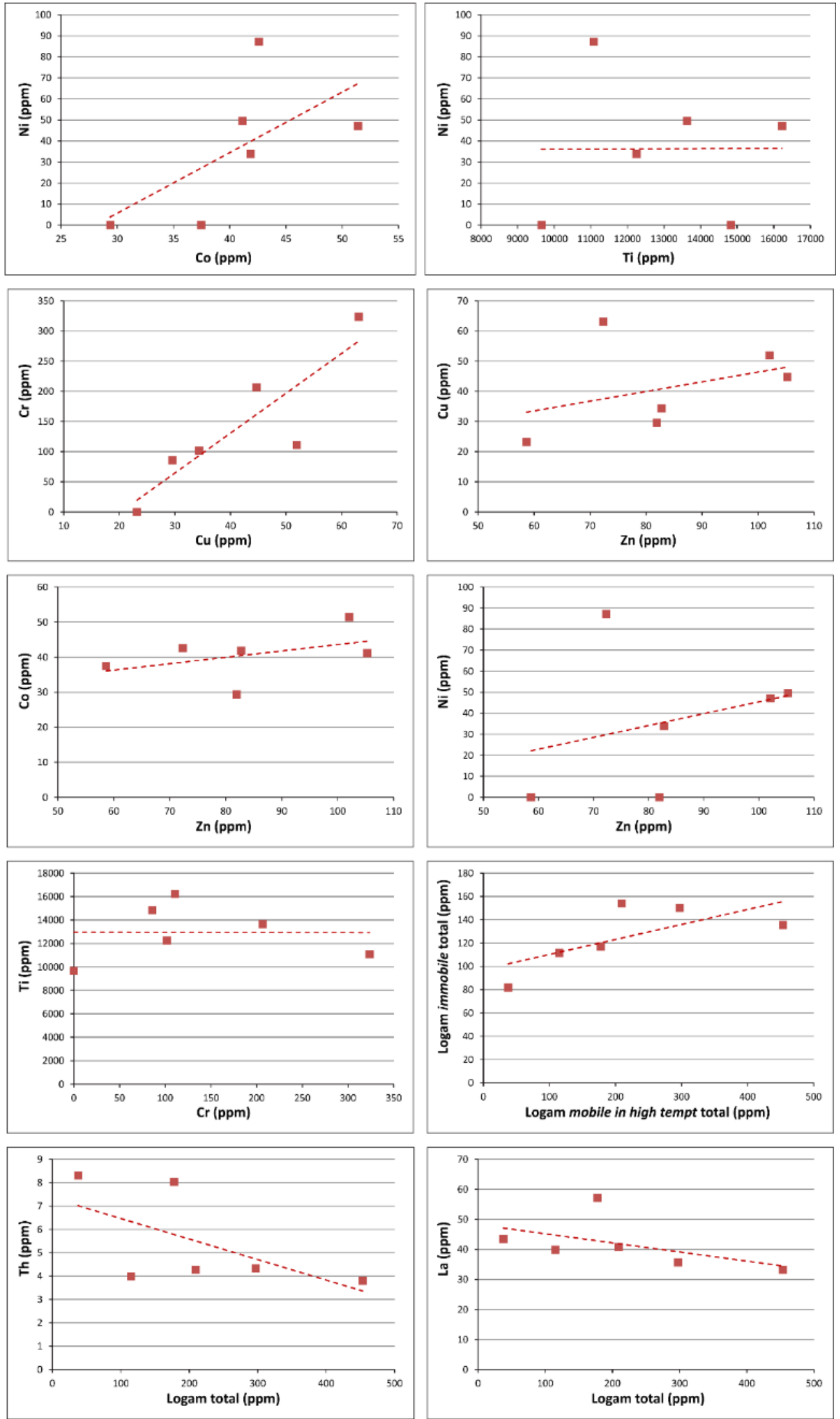

Gambar 5. Diagram Harker basal alkali pada daerah penelitian. 

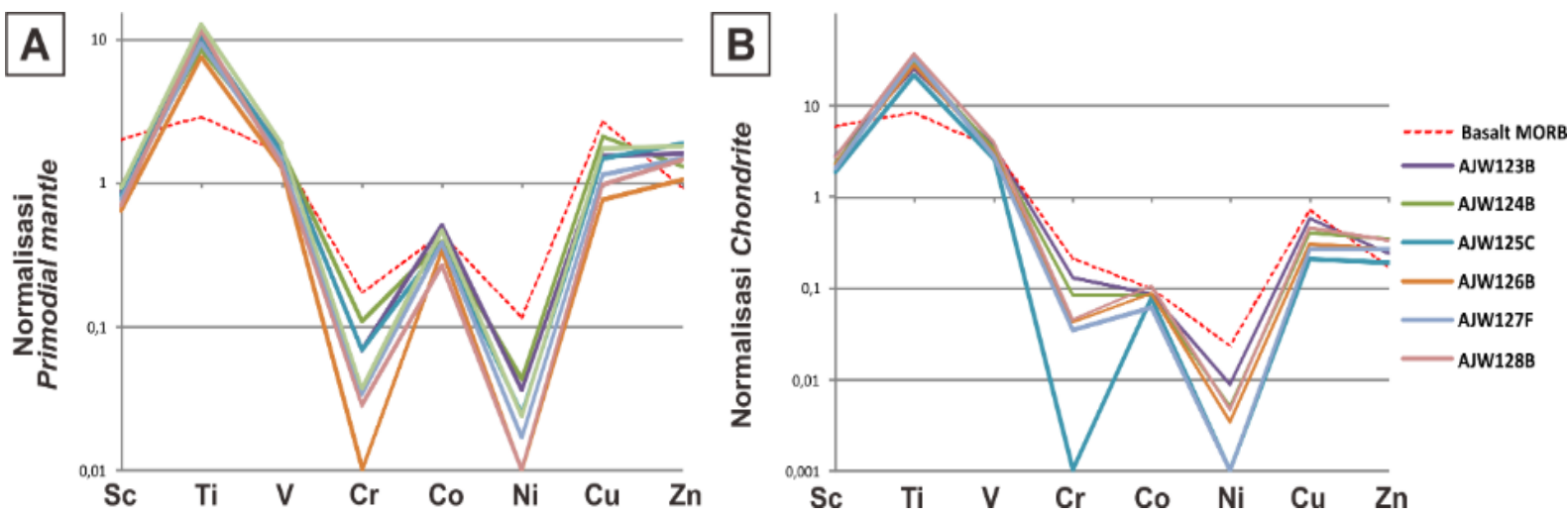

Gambar 6. Diagram laba-laba unsur logam pada basal alkali di daerah penelitian dibandingkan unsur logam pada MORB [16] (a) Normalisasi unsur terhadap primodial mantle dan (b) normalisasi unsur terhadap chondrite.
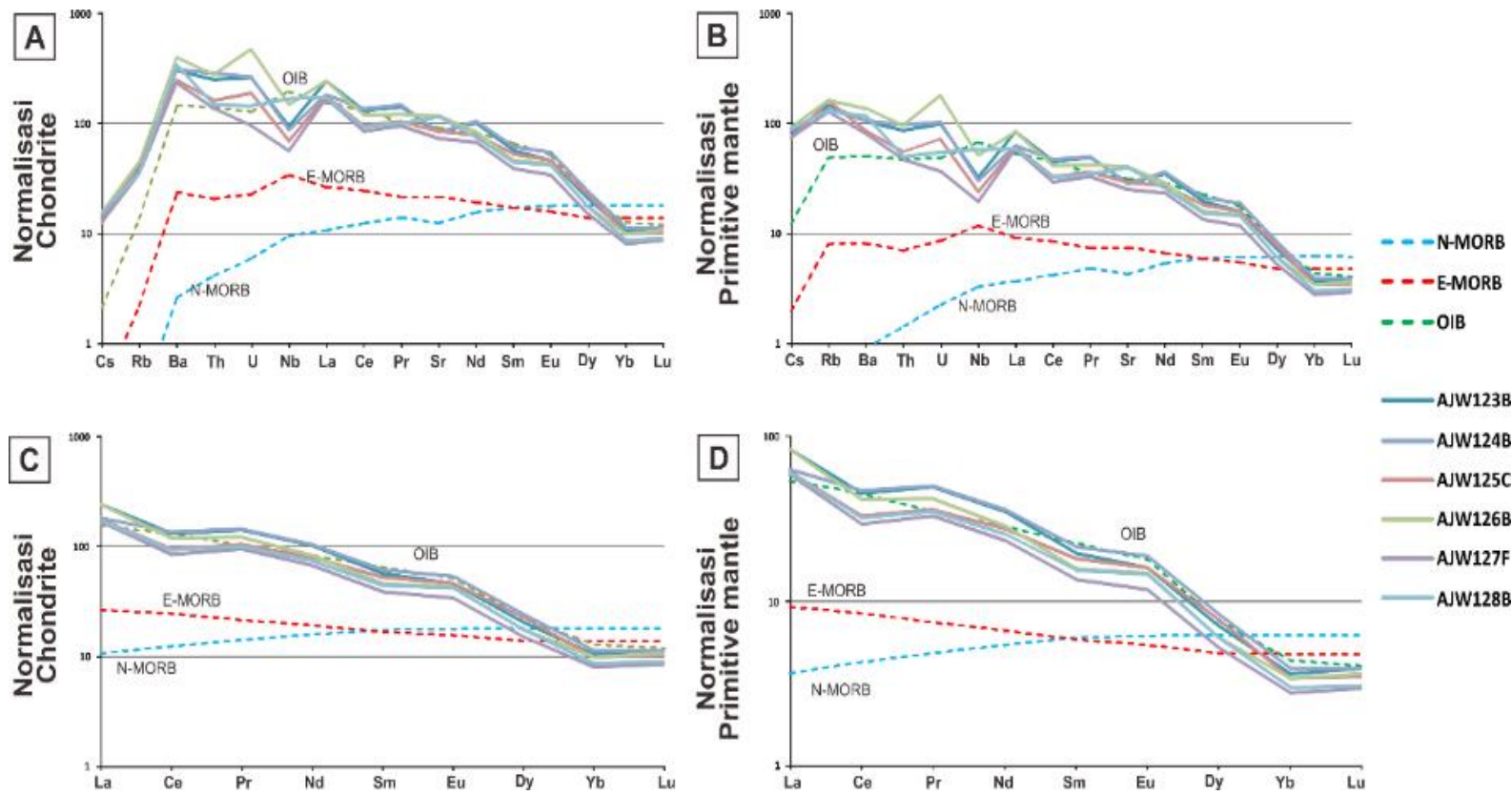

Gambar 7. Diagram laba-laba pada daerah penelitian: (a) Diagram multielemen dinormalisasi terhadap chondrite, (b) Diagram multielemen dinormalisasi terhadap primitive mantle, (c) Diagram unsur tanah jarang dinormalisasi terhadap chondrite, dan (d) Diagram unsur tanah jarang dinormalisasi terhadap primitive mantle. Normalisasi unsur tanah jarang dengan koefisien chondrite dan primitive mantle milik Sun dan McDonough [13] dengan pembanding N-MORB, E-MORB dan OIB Sun dan McDonough [13].

Diagram unsur jarang $\mathrm{Zr} / \mathrm{Ti}$ vs $\mathrm{Nb} / \mathrm{Y}$ [16] yang digunakan untuk menentukan nama batuan menunjukkan bahwa keenam sampel merupakan basal alkali (Gambar 4). Diagram Harker unsur jejak digunakan untuk membandingkan hubungan unsur logam immobile pada temperatur tinggi $(\mathrm{Co}, \mathrm{Ni}$, dan $\mathrm{Ti})$, logam mobile pada temperatur tinggi $(\mathrm{Cr}$,
$\mathrm{Cu}$, dan $\mathrm{Zn}$ ), serta unsur tanah jarang (Th dan La).

Hasil plot diagram Harker unsur logam menunjukkan unsur logam immobile memiliki korelasi positif terhadap unsur logam immobile lainnya ( $\mathrm{Ni}$ vs $\mathrm{Co}$ dan $\mathrm{Ni}$ vs $\mathrm{Ti}$ ) sehingga diintepretasikan bahwa pengayaan unsur logam immobile berhubungan satu sama 
lain dengan pengayaan unsur logam immobile lainnya (Gambar 5). Hasil plot unsur mobile pada temperatur tinggi juga menunjukkan korelasi positif terhadap unsur mobile lainnya sehingga diintepretasikan bahwa pengayaan unsur logam mobile berhubungan dengan pengayaan unsur logam mobile yang lainnya (Cr vs $\mathrm{Cu}$ dan $\mathrm{Cu}$ vs $\mathrm{Zn}$ ).

Berdasarkan perbandingan diagram labalaba unsur logam (Gambar 6) dengan basal MORB [17] terjadi pengayaan unsur Ti yang dibuktikan dengan kehadiran mineral titanaugit pada sampel petrografi batuan (Gambar 3b). Secara umum keenam sampel basal alkali menunjukkan pola yang identik dengan pola OIB (Gambar 7). Berdasarkan diagram laba-laba unsur tanah jarang terjadi pengayaan unsur LILE (Cs, Rb, Ba, dan $\mathrm{Sr}$ ) yang mengindikasikan kontaminasi sedimen ataupun kerak benua. Unsur $\mathrm{Nb}$ relatif mengalami pemiskinan yang mengindikasikan adanya pengaruh aktivitas subduksi pada daerah penelitian. Unsur $\mathrm{Th}$ dan $\mathrm{U}$ juga menunjukkan pengayaan cukup signifikan yang diperkirakan berasal dari pengayaan batuan sedimen maupun kerak benua atau langsung berasal dari plume yang bersumber dari astenosfer. Diagram diskriminan unsur jejak V-Ti [18] menunjukkan basal alkali Formasi Manamas berasal dari Ocean Islandalkaline Basalt. Diagram Th-Co [19] menunjukkan basal dengan kalium tinggi dan sosonitik (Gambar 8a dan 8b) sedangkan pada diagram Nb/La-La/Yb dan Th/Nb-La/Yb [20] menunjukkan basal terbentuk pada Ocean Island hingga Alkaline Basalt (Gambar 8c dan 8d). Diagram Rb/Y-Nb/Y dan Nb-Th [21] digunakan untuk mengetahui kecenderungan pengayaan unsur yang terjadi pada batuan. Hasilnya menunjukkan basal alkali mengalami pengayaan unsur yang dikontrol oleh fluid related enrichment dan juga melt related enrichment (Gambar 8e dan 8f). Karakter pengayaan ini diintepretasikan terjadi akibat adanya peleburan magma akibat subduksi lempeng samudra sehingga magma mengalami pengayaan hidroksil (fluid) yang juga dipengaruhi oleh adanya mantle plume yang bercampur.

\section{DISKUSI}

Batuan beku pada daerah penelitian tidak terpetakan pada Peta Geologi Lembar Kupang-Atambua [1]. Batuan beku pada daerah penelitian dimasukkan sebagai Formasi Manamas berumur Miosen AkhirPliosen oleh Widiatama dkk. [12]. Penelitian Ishikawa dkk. [3] dan Kaneko dkk. [4], menjelaskan bahwa penipisan kerak yang terjadi di depan Busur Gunung api Banda segmen Timor memicu pembentukan fore arc ophiolite (FAO). Salah satu konstituen penyusunnya adalah basal subalkali dengan struktur bantal bersifat toleitik [12]. Selain basal subalkali, di Sungai Bihati Baun juga dijumpai batuan basal alkali yang memiliki karakteristik geokimia high-alkali hingga sosonitik yang berasal dari oceanic island basalt. Perbedaan kedua jenis batuan basal ini menunjukkan fenomena tektonik yang berbeda secara signifikan pada saat pembentukannya.

Penelitian batuan beku di Pulau Timor yang menunjukkan asal dari OIB mengaitkan kehadiran batuan ini sebagai produk pemekaran benua [11], [22]. Meskipun begitu tidak ada uji umur batuan beku sehingga penarikan hipotesis ini hanya berdasarkan keselarasan episode tektonik Pulau Timor [22]. Hal ini membuka kesempatan untuk mengajukan hipotesis baru tentang genesa pembentukan batuan beku dengan afinitas OIB. 

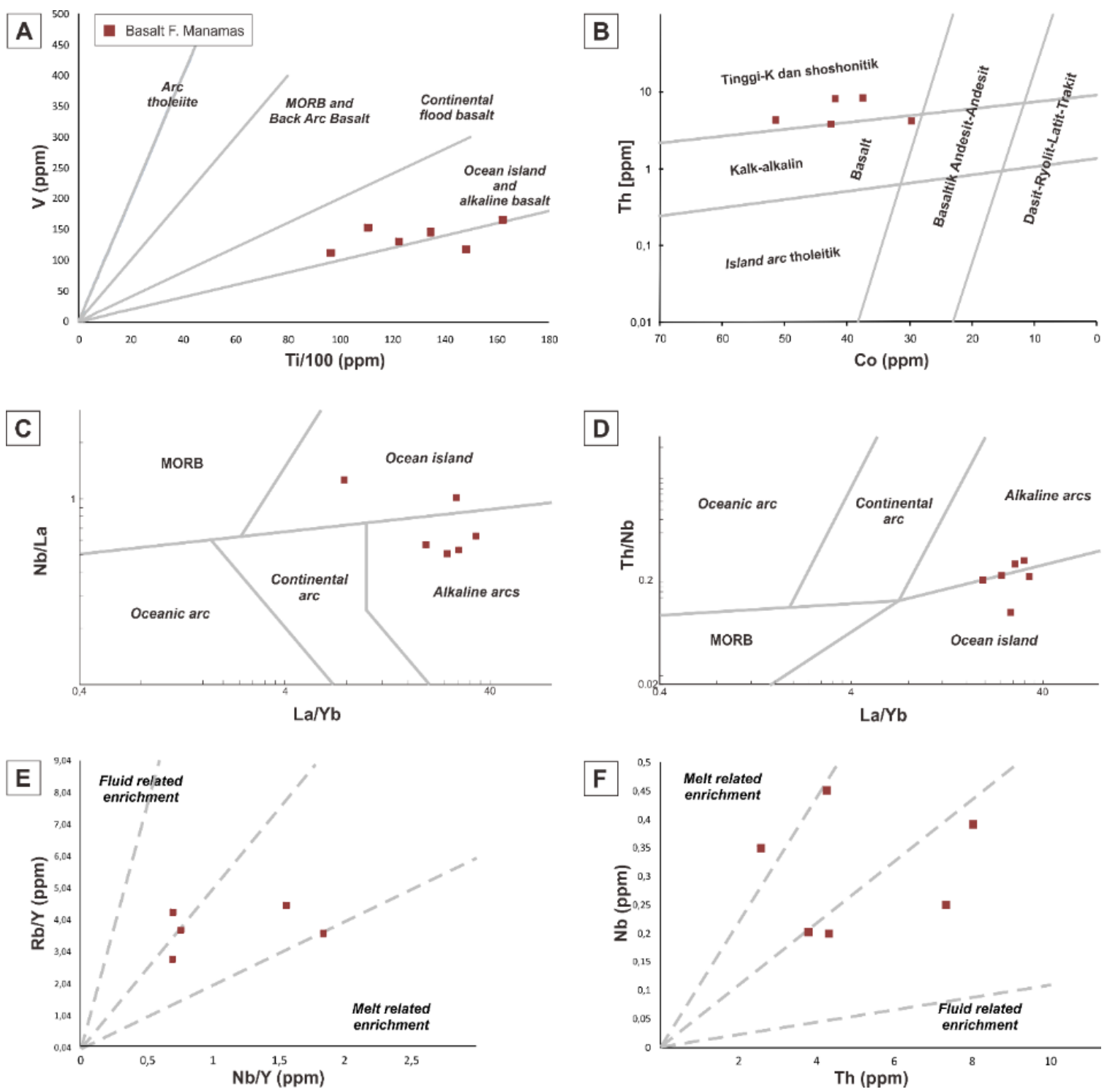

Gambar 8. Diagram diskriminan basal alkali Formasi Manamas (a) Diagram V-Ti [18], (b) Diagram Th-Co [19], (c) $\mathrm{Nb} / \mathrm{La}-\mathrm{La} / \mathrm{Yb}$, (d) Th/Nb-La/Yb [20], (e) Rb/Y-Nb/Y, (f) Nb-Th [21].

Data geokimia batuan menunjukkan basal alkali terbentuk akibat adanya percampuran antara magma subduksi dengan magma yang berasal dari astenosfer. Hal ini dikonfirmasi dengan petrografi batuan yang menunjukkan tekstur zoning, sieve, dan keterdapatan rim/cincin titanomagnet pada mineral orthopiroksen yang mengindikasikan adanya pencampuran dengan magma baru yang bersuhu lebih panas pada reservoir magma. Magma yang berumur relatif lebih tua bersumber dari reservoir basal subalkali yang terbentuk akibat vulkanisme depan busur gunung api [3], [12]. Hal ini terjadi akibat pergerakan Lempeng Australia ke utara dengan kecepatan sekitar empat milimeter per tahun [23], [24]. Lempeng Samudra Hindia mengalami mekanisme progressive rollback di bagian selatan Pulau Timor sehingga membentuk cekungan belakang busur yang menjadi Lempeng Samudra Banda dan dalaman Webber yang merupakan cekungan depan busur gunung api [25-27]. Produk vulkanisme akibat penipisan 
cekungan depan busur hadir di selatan Pulau Timor sebagai batuan ekstrusif basal bersifat subalkali berstruktur basal Formasi Manamas yang berumur antara 6-3 juta tahun lalu [12].

Hadirnya batuan ofiolit di Timor Barat menunjukkan adanya proses doming yang disebabkan oleh buoyancy akibat putusnya lempeng samudra yang menunjam/slab break off [4], [5], [7], [28], [29]. Hal ini mempengaruhi perilaku magma dalam dua domain, yaitu: 1) Proses bouyancy akan menyebabkan kerak mengalami pengangkatan sehingga memicu terjadinya underplating magma hasil peleburan sisa lempeng samudra yang tersubduksi yang membentuk kantong magma di bawah kerak Alokton. Magma yang terjebak di bawah kerak akan menyebabkan batuan kerak benua Gondwana-Busur Gunung api (Alokton), yang berisi batuan sedimen kontinen tidak termetamorfisme, terasimilasi sehingga magma menunjukkan karakteristik $\mathrm{K}_{2} \mathrm{O}$, $\mathrm{Na}_{2} \mathrm{O}$, dan $\mathrm{CaO}$ tinggi. Meskipun begitu belum dapat ditentukan secara pasti apa yang lebih dominan dalam mempengaruhi pengayaan unsur yang berasosiasi dengan kontinen, apakah akibat tersubduksinya transitional crust Australia ataukah akibat asimilasi magma dari proses underplating; 2) Robekan lempeng samudra akan mempercepat laju slab pull untuk mencapai astenosfer. Kerak samudra yang terobek bergerak mendekati mantel atas dan mengalami pelelehan (melting) sehingga bercampur dengan magma yang berasal dari astenosfer atau reservoir OIB. Proses pencampuran ini menghasilkan magma basaltik yang memiliki karakteristik sama dengan Oceanic Island Basalt [30]. Hal ini ditunjukkan dengan karakteristik unsur tanah jarang hasil normalisasi primitive mantle dan chondrite yang memiliki pola identik dengan OIB (Gambar 7). Magma OIB bergerak naik (upwelling) sebagai plume dan mengalami percampuran dengan magma toleitik membentuk underplating yang telah melelehkan batuan kerak benua-busur gunung api (Alokton).

Proses asimilasi ditunjukkan oleh data unsur tanah jarang pada diagram perbandingan antara $\mathrm{Rb} / \mathrm{Y}$ terhadap $\mathrm{Nb} / \mathrm{Y}$ dan $\mathrm{Nb}$ terhadap Th (Gambar 8). Interaksi ini menghasilkan magma basaltik bersifat high alkali-sosonitik dengan nilai konsentrasi $\mathrm{SiO}_{2}$ : 39,30-47,48 wt\% dan $\mathrm{K}_{2} \mathrm{O}: 1,99-4,44$ $\mathrm{wt} \%$. Kehadiran tekstur sieve pada mineral plagioklas dan pengayaan unsur LILE dalam sampel batuan basal alkali menjadi bukti adanya proses asimilasi dengan batuan bersifat granitik ataupun batuan sedimen yang selanjutnya hadir sebagai intrusi pada batuan beku Formasi Manamas yang dijumpai di Sungai Bihati, Baun, Timor (Gambar 9) yang diperkirakan memiliki umur tidak lebih muda dari 3 juta tahun yang lalu. Batuan beku yang berafinitas Oceanic Island Basalt memiliki pengayaan unsur jejak dan unsur tanah jarang, termasuk di dalamnya unsur-unsur radioaktif seperti uranium, lantanum, dan sebagainya, sehingga keberadaan afinitas batuan ini dapat menjadi petunjuk eksplorasi mineral di Indonesia.

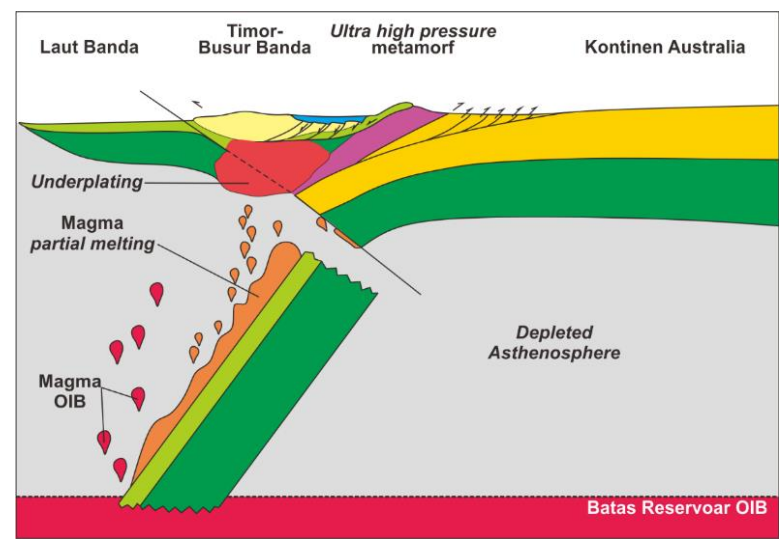

Gambar 9. Model pembentukan basal alkali Formasi Manamas (modifikasi [5]). 


\section{KESIMPULAN}

Berdasarkan karakter geokimia, sampel Formasi Manamas berupa basal dengan afinitas alkali yang memiliki pengayaan unsur $\mathrm{Na}_{2} \mathrm{O}$ dan $\mathrm{K}_{2} \mathrm{O}$. Serta pola pengayaan unsur tanah jarang yang identik dengan OIB. Pengayaan unsur LILE menunjukkan adanya proses asimilasi dan kontaminasi material kerak benua berupa batuan sedimen atau granitik. Basal alkali terbentuk sebagai hasil intrusi sedangkan pengayaan unsur kimia disebabkan oleh dua mekanisme yang berbeda yaitu fluid related enrichment yang berkaitan dengan aktifitas subduksi lempeng Samudra Hindia di bawah Busur Banda dan juga melt related enrichment yang diperkirakan berasal dari sisa lempeng Samudra Hindia yang patah yang masuk ke dalam zona reservoir OIB sehingga menghasilkan plume. Kedua magma lalu bercampur dan mengalami underplating di bawah Busur Banda.

\section{UCAPAN TERIMA KASIH}

Ucapan terima kasih kepada anggota tim survei Cekungan Sawu yang telah membantu pengambilan data lapangan dan Laboratorium Geologi Kuarter yang telah membantu analisis sampel batuan serta semua pihak yang telah berkontribusi dalam mewujudkan tulisan ini .

\section{DAFTAR PUSTAKA}

[1] H. M. D. Rosidi, S. Tjokrosapoetro, S. Gafoer, dan K. Suwitodirdjo. "Peta Geologi Lembar KupangAtambua, Timor, skala 1:250.000," Bandung: Pusat Penelitian dan Pengembangan Geologi, 1979.

[2] J. Sopaheluwakan, "Ophiolite Obduction in the Mutis Complex, Timor, Eastern Indonesia: An Example of Inverted, Isobaric, Medium-High Pressure Metamorphism," Ph. D thesis, Vrije Universiteit, Amsterdam, the Netherlands, 1990

[3] A. Ishikawa, Y. Kaneko, A. Kadarusman, dan T. Ota, "Multiple Generations of Forearc MaficUltramafic Rocks in the Timor-Tanimbar Ophiolite, Eastern Indonesia," Gondwana Research, vol. 11, hal. 200-217, 2007.
[4] Y. Kaneko, S. Maruyama, A. Kadarusman, T. Ota, M. Ishikawa, T. Tsujimori, A. Ishikawa, dan K. Okamoto, "On-going Orogeny in The Outer-Arc of the Timor-Tanimbar Region, Eastern Indonesia", Gondwana Research, vol. 11, hal. 218-233, 2007

[5] A. Kadarusman, S. Maruyama, Y. Kaneko, T. Ota, A. Ishikawa, J. Sopaheluwakan, dan S. Omori, "World's Youngest Blueschist Belt from Leti Island in the Nonvolcanic Banda Outer Arc of Eastern Indonesia", Gondwana Research, vol. 18, hal. 189-204, 2010

[6] M. G. Audley-Charles, Ed., The Geology of Portuguese Timor, London: Blackwell Scientific Publications, 1968.

[7] M. G. Audley-Charles, "Tectonic Post-Collision Processes in Timor," dalam: R. Hall, M.A. Cottam, dan M.E.J Wilson, Eds., The SE Asian Gateway: History and Tectonics of the Australia-Asia Collision, London: The Geological Society, 2011, hal. 241-266.

[8] R. Harris, "Rise and Fall of The Eastern Great Indonesian Arc Recorded by the Assembly, Dispersion and Accretion of the Banda Terrane, Timor," Gondwana Res, vol. 10, no. 3-4, hal. 207231, 2006.

[9] T. R. Charlton, A. J. Barber, dan S. T. Barkham, "The Structural Evolution of the Timor Collision Complex, Eastern Indonesia." Journal of Structural Geology, vol. 13, hal. 489-500, 1991.

[10] H. Wensink dan S. Hartosukohardjo, "Paleomagnetism of Younger Volcanics from Western Timor, Indonesia," Earth and Planetary Science Letters, 100, hal. 94-107, 1990.

[11] J. Wahyudiono, I. Safri, A. Sudrajat, dan H. Panggabean, "Geokimia Batuan Gunungapi di Pulau Timor Bagian Barat dan Implikasi Tektoniknya," Jurnal Geologi dan Sumberdaya Mineral, vol. 17, no. 4, hal. 241-252, 2016

[12] A. J. Widiatama, L. D. Santy, J. Wahyudiono, S. Widyastuti, dan L. F. Rahmatillah, "Karakteristik Geokimia Basalt Busur Gunungapi Tholeitik Formasi Manamas di Sungai Metan, Baun, Timor," Jurnal Geologi dan Sumberdaya Mineral, vol. 21. no.3, hal 149-156, 2020

[13] S. S. Sun dan W. F. McDonough," Chemical and Isotopic Systematics of Oceanic Basalt: Implications for Mantle Composition and Process" dalam: Magmatism in the Ocean Basins A. D. Saunders dan M. J. Norry Ed. London: Geological Society 1989, hal. 313-345.

[14] M. L. Renjith, "Micro-textures in Plagioclase from 1994-1995 Eruption, Barren Island Volcano: Evidence of Dynamic Magma Plumbing System in the Andaman subduction zone," Geoscience Frontiers, vol. 5, hal. 113-126, 2014.

[15] A. L. Streckeisen, "To Each Plutonic Rock Its Proper Name," Earth Science Reviews, vol. 12, hal. 1-33, 1976 
[16] J. A. Winchester dan P. A. Floyd, "Geochemical Magma Type Discrimination: Application to Altered and Metamorphosed Basic Igneous Rocks," Earth and Planetary Science Letters, vol. 28, no.3, hal. 459-469, 1976.

[17] C. H. Langmuir, J. F. Bender, A. E. Bence, G. N. Hanson, dan S. R. Taylor "Petrogenesis of Basalts from the F AMOVS Area: Mid-Atlantic Ridge," Earth Planet. Sci. Lett., vol. 36, hal. 133-156, 1977.

[18] J. W. Shervais, "Ti-V Plots and the Petrogenesis of Modern and Ophiolitic Lavas," Earth Planet. Sci. Lett., vol. 59, hal. 101-118, 1982.

[19] A. R. Hastie, A. C. Kerr, J. A. Pearce, dan S. F. Mitchell, "Classification of Altered Volcanic Island Arc Rocks using Immobile Trace Elements: Development of the Th-Co Discrimination Diagram," Journal of Petrology, vol. 48, hal. 2341-2357, 2007.

[20] K. Hollocher, P. Robinson, E. Walsh, dan D. Roberts, "Geochemistry of Amphibolite-Facies Volcanics and Gabbros of the Støren Nappe in Extensions West and Southwest of Trondheim, Western Gneiss Region, Norway: A Key to Correlations and Paleotectonic Settings," Am. Jour. Sci., vol. 312, no. 4, hal. 357-416, 2012.

[21] J. J. Zhao dan M. F. Zhou," Neoproterozoic Mafic Intrusions in the Panzhihua District, SW China: Implications for Interaction Between Subducted Slab and Mantle Wedge," Geochim. Cosmochim. Acta, vol. 70, hal. A740-A1740, 2006.

[22] R. F. Berry dan G. A. Jenner, "Basalt Geochemistry as a Test of the Tectonic Models of Timor," J. geol. Soc. London, vol. 139, hal. 593604, 1982.
[23] A. N. Richardson dan D. J. Blundell, "Continental Collision in the Banda arc," dalam: Tectonic Evolution of Southeast Asia, R. Hall, dan D. Blundell, Ed. London, Geological Society, 1996, hal. 47-60.

[24] H. Nugroho, R. Harris, A. W. Lestariya, dan B. Maruf, "Plate Boundary Reorganization in the Active Banda Arc-continent Collision: Insights from New GPS Measurements," Gondwana Research, vol. 479, hal. 52-65, 2009.

[25] R. Hall, "Australia-SE Asia Collision: Plate Tectonics and Crustal Flow" dalam: The SE Asian Gateway: History and Tectonics of the AustraliaAsia Collision, R. Hall, M. A. Cottam, dan M. E. J Wilson, Eds. London: The Geological Society, 2011, hal. 75-109.

[26] R. Hall, "Late Jurassic-Cenozoic Reconstructions of the Indonesian Region and the Indian Ocean," Tectonophysics, vol. 570, hal. 1-41, 2012.

[27] R. Hall dan I. Sevastjanova, "Australian crust in Indonesia," Australian Journal of Earth Sciences, vol. 59, hal. 827-844, 2012.

[28] F. H. Chamalaun dan A. Grady, "The Tectonic Development of Timor: a New Model and Its Implications for Petroleum Exploration," Australian Petroleum Exploration Association Journal, vol. 18, hal. 102-108, 1978.

[29] C. E. Stanley dan R. Harris, "Tectonic Evolution of Forearc Nappes of the Active Banda Arccontinent Collision: Origin, Age, Metamorphic History and Structure of the Lolotoi Complex, East Timor," Tectonophysics, vol. 479, hal. 66-94, 2009.

[30] M. Wilson, Ed., Igneous Petrogenesis a Global Tectonic Approach. Dordrecht: Springer, 1989. 